\title{
Impact of Urea as Nitrogen Source and Pix as Growth Regulator on Cotton (Gossypium hirsutum L)
}

\author{
Esmaeil Yasari ${ }^{1} \&$ Abed Vahedi $^{2}$ \\ ${ }^{1}$ Department of Agriculture, Payame Noor University, Iran \\ ${ }^{2}$ Department of Agronomy and Plant Breeding, Islamic Azad University, Qaemshahr Branch, Iran \\ Correspondence: Esmaeil Yasari, Agriculture Department, Payame Noor University, Iran. E-mail: \\ e_yassari@yahoo.com
}

Received: May 16, 2011 Accepted: June 9, 2011 Online Published: June 26, 2012

doi:10.5539/ijb.v4n3p140

URL: http://dx.doi.org/10.5539/ijb.v4n3p140

\begin{abstract}
In order to study the effects of the application of various amounts of nitrogen fertilizers and Pix $35 \%$ growth regulator on the morphological features of the Sahel cultivar of cotton (Gossypium hirsutum L.), and on the unginned cotton yield of this cultivar, an experiment was carried out in the factorial design in the randomized complete block format with three replications at the Bayekola Agronomical Research Station in 2009. The factors studied included the amounts of nitrogen fertilizers and of the cotton growth regulator Pix $35 \%$ used in the experiment. Results obtained showed that the minimum plant height was obtained in the control treatment $(72.93 \mathrm{~cm})$, and that plant height increased with nitrogen application and reached its maximum $(77.59 \mathrm{~cm})$ when $225 \mathrm{Kg} . \mathrm{h}$ of nitrogen was used. The analysis of the variance of the data indicated that the effects of applying various levels of Pix were very significantly different, so that the greatest plant height was observed in the Pix control treatment $(90.94 \mathrm{~cm})$, and it significantly decreased by Pix application and reached $65 \mathrm{~cm}$ when $300 \mathrm{~g} . \mathrm{h}$ of Pix was applied (which was an almost $40 \%$ reduction). Furthermore, when nitrogen fertilizers were applied, the unginned cotton yield significantly went up, and this increase in yield continued up to the level of using 150 Kg. h nitrogen; however, when the level of nitrogen application reached $225 \mathrm{Kg} . \mathrm{h}$, the yield started to go down. As a whole, the lowest yield was obtained when nitrogen was not applied (which was the control with a yield of $1469 \mathrm{Kg}$ of unginned cotton per hectare), and the maximum yield ( $2825 \mathrm{Kg} . \mathrm{h}$ of unginned cotton per hectare) was achieved when $150 \mathrm{Kg}$ of nitrogen per hectare was used i.e., the unginned cotton yield went up by $14 \%$ when $150 \mathrm{Kg}$ of nitrogen per hectare was applied. In our study, it was observed that Pix did not have much influence on increasing yield: the minimum yield $(2529 \mathrm{Kg}$ of unginned cotton per hectare) was observed in the treatment of applying $100 \mathrm{~g}$. h of Pix, and the maximum yield (2669 $\mathrm{Kg}$ of unginned cotton per hectare) by using 200 gh of Pix. Comparison of the interaction effects of the level of Pix and nitrogen application indicated that, among all the treatments, the maximum yield of unginned cotton $(3010 \mathrm{~K} . \mathrm{h})$ was achieved when $150 \mathrm{Kg}$. $\mathrm{h}$ of nitrogen and 200 g.h Pix were applied. These results also showed that in the treatments of using $150 \mathrm{Kg}$ nitrogen per hectare, and applying $150 \mathrm{Kg}$. nitrogen plus $300 \mathrm{~g}$ Pix per hectare also, high yield potentials (close to 3 tons per hectare) were created. The minimum yield of unginned cotton ( $2230 \mathrm{Kg} . \mathrm{h})$ belonged to the treatment of using 200 grams of Pix per hectare.
\end{abstract}

Keywords: cotton, nitrogen, pix, morphological features

\section{Introduction}

The crop plant cotton (Gossypiun hirsutum L.) which is one of the important crops used in industry is also called the white gold. Crop plants, including cotton, are faced with various limitations, such as limited plant nutrients in the soil. One of the most important plant nutrients needed for cotton to grow, and which greatly affects the yield of the cotton crop, is nitrogen. However, excessive application of nitrogen causes an increase in vegetative growth, and disturbs the balance between the vegetative and the reproductive growth; and thus decreases the yield of unginned cotton, or does not further raise yield. Therefore, determination of the suitable amount of nitrogen required by cotton in each region enjoys special priority. This is of special importance in the north of Iran, where harvesting cotton coincides with the rainy season in the fall. Excessive application of nitrogen delays the maturity of the crop, and the coincidence of the harvest with rainy weather in the fall reduces the quality of cotton fibers, especially in the second and third picks. Therefore, finding a solution for having early maturing 
crops is worthy of consideration. Among the substances that have attracted the attention of scientists and researchers who are after finding such a solution are the growth regulators that have various and desirable effects on different crop plants, including cotton. One of these growth regulators, which is widely used in cotton, is Mepiquat chloride, which has the common name of Pix. Gerbin et al. (1996), in their study of the effects of using Pix on the growth of the roots and the aerial parts of cotton, found that Pix significantly increases the yield of cotton and also the ratio of cotton seed to the total dry matter produced. Pix can cause early maturity of the crop, so that there are more bolls in the middle and lower parts of plants sprayed with Pix. As these bolls have access to more plant nutrients, they mature early; and in this way, crop yield goes up, especially in the first pick (Kerby et al., 1990). Pix also causes the plants to become smaller, and hence it becomes possible to have more plants per unit area, which can lead to an increase in yield per unit area (Stuart et al., 2004). This study was conducted with the purpose of finding the most suitable amounts of nitrogen and Pix to be applied to the cotton crop; so that a step is taken in getting to know the factors that can increase cotton yield, and improve the quality of its fibers, in the province of Mazandaran.

\section{Methods and Materials}

In order to investigate the effects of applying different levels of nitrogen and the growth regulator Pix $35 \%$ on the unginned yield and the morphological features of the Sahel cultivar of cotton, an experiment was conducted in the Agronomical Research Station of Bayekola in 2009. The geographical, and the other, characteristics of Bayekola are as follows: longitude: $31.3^{\circ}$ East, latitude: $36.42^{\circ}$ East, altitude: -18 meters above sea level, average annual rainfall: 680 millimeters, soil: clayey, $\mathrm{pH}: 8$. The study was conducted in the factorial design $\left(4^{2}\right)$ in the randomized complete block format with three replications. The factors included the amounts of nitrogen $(\mathrm{N})$ and the growth regulator Pix 35\% (P) applied to the crop plant. The levels of nitrogen in the experiment were as follows: no nitrogen applied (NO), as the control, 75 kilograms of pure nitrogen per hectare (N1), 150 kilograms of pure nitrogen per hectare (N2), and 225 kilograms of pure nitrogen per hectare (N3). Nitrogen was applied in the form of urea as top dressing at the stages of bud formation and at the start of stem elongation. The Pix factor included the control treatment (PO), in which no Pix was applied, and the treatments of using 100 grams (P1) , 200 grams (P2), and 300 grams (P3) of Pix 35\% per hectare at the start of flowering (it was sprayed when there were 10 white flowers in every meter of the planted lines). Pix $35 \%$ is the common name of a growth regulator with the name of Dimethyl - piperidium chloride, which is an odorless powder that readily dissolves in water.

\section{Results and Discussion}

\subsection{Height of the Plants}

Results obtained showed that the differences between the various levels of nitrogen applied, and also the interaction effects of using nitrogen plus applying Pix 35\%, were not significant regarding plant height (Table 1). Nevertheless, the shortest plants $(72.93 \mathrm{~cm})$ were observed in the control, while with an increase in nitrogen applied, plant height also went up; so that at $225 \mathrm{Kg} . \mathrm{h}$ of nitrogen, the tallest plants $(77.59 \mathrm{~cm}$ were produced) (Table 2). The reason for this could be that nitrogen increased the internodal length -i.e., when more nitrogen became available, the vegetative growth increased and plants became taller. The analysis of the variance indicated that the differences between the various levels of Pix on the feature of plant height were very significant (Table 1). Comparison of the means of different levels of Pix applied showed that the tallest plants $(90.94 \mathrm{~cm})$ belonged to the control treatment of Pix, while by applying Pix the height of plants significantly decreased, and was reduced to $65 \mathrm{~cm}$ (which was about $40 \%$ less than the height of plants in the control) when 300 g.h Pix was used. The reason for the decrease in height caused by applying Pix could be that Pix inhibits the production of gibberellic acid. Gibberellic acid is responsible for longitudinal growth and it increases plant growth; and Pix in fact reduces the longitudinal growth of the cotton plants by preventing the synthesis of gibberellic acid. These results are consistent with the findings of Carualho et al. (2005). Comparison of the interaction effects of application of nitrogen and Pix indicated that maximum plant height $(94 \mathrm{~cm})$ was obtained by using $225 \mathrm{Kg} . \mathrm{h}$ nitrogen, and the minimum plant height $(61 \mathrm{~cm})$ was observed when 300 grams of Pix per hectare was applied (Figure 1).

\subsection{Number of Nodes on the Main Stem}

The analysis of the variance showed that there was no significant difference among the various levels of nitrogen regarding the number of nodes on the main stem (Table 1). However, the difference among the various levels of Pix concerning the number of nodes on the main stem was very significant. Comparison of the means indicated that, in the Pix treatments, the greatest number of nodes on the main stem was achieved in the control, and that the number of nodes decreased when higher levels of Pix was applied, so that when 300 grams of Pix per hectare 
was used the lowest of nodes on the main stem was observed (Table 2). This decrease in the number of nodes is due to the inhibitory effects of Pix - Pix inhibits the synthesis of gibberellic acid and thus prevents the increase in the number of nodes and the elongation of stems. Therefore, one of the reasons for the shortening of the main stem resulting from the application of Pix could probably be this reduction in the number of nodes. Comparison of the interaction effects of the application of Pix and nitrogen indicated that the maximum number of nodes on the main stem (14.5) was achieved when $150 \mathrm{Kg} . \mathrm{h}$ of nitrogen was used, and the minimum (10.8) when 300 grams of Pix plus $225 \mathrm{Kg}$ of nitrogen per hectare were applied (Figure 2).

Table 1. Analysis of variation of the studied traits

\begin{tabular}{ccccccc}
\hline $\begin{array}{c}\text { Source of } \\
\text { Variation }\end{array}$ & \multicolumn{5}{c}{ MS } \\
\cline { 2 - 7 } & Plant Height & $\begin{array}{c}\text { No. Node } \\
\text { on main } \\
\text { stem }\end{array}$ & $\begin{array}{c}\text { Internodal } \\
\text { length }\end{array}$ & $\begin{array}{c}\text { Number of } \\
\text { reproductive } \\
\text { branches }\end{array}$ & $\begin{array}{c}\text { Length of } 3^{\text {rd }} \\
\text { reproductive } \\
\text { Branch }\end{array}$ & Cotton yield \\
\hline Replication & $48.1450 \mathrm{~ns}$ & $3.2758 \mathrm{~ns}$ & $0.1732 \mathrm{~ns}$ & $0.035 \mathrm{~ns}$ & $14.1705 \mathrm{~ns}$ & $67592.6 \mathrm{~ns}$ \\
$\mathrm{~N}$ & $55.41 \mathrm{~ns}$ & $1.1996 \mathrm{~ns}$ & $0.0901 \mathrm{~ns}$ & $0.59 \mathrm{~ns}$ & $24.7566 \mathrm{~ns}$ & $290584.694 * *$ \\
$\mathrm{P}$ & $1499.976 * *$ & $10.1476 * *$ & $2.94 * *$ & $4.1823 * *$ & $61.83 * *$ & $45528.25 \mathrm{~ns}$ \\
$\mathrm{~N} * \mathrm{P}$ & $13418 \mathrm{~ns}$ & $1.0219 \mathrm{~ns}$ & $0.2812 \mathrm{~ns}$ & $0.8532 \mathrm{~ns}$ & $24.3411 \mathrm{~ns}$ & $94113.528 \mathrm{~ns}$ \\
Error & 23.896 & 0.991 & 0.1641 & 1.133 & 11.5 & 57535.201 \\
$\mathrm{CV}(\%)$ & 6.52 & 7.75 & 6.94 & 16.84 & 17.71 & 9.18 \\
\hline
\end{tabular}

$*$ and ** show the least differences at 1 and 5 level of probability respectively and ns shows none significant difference.

Table 2. Effects of nitrogen and pix application on cotton different features

\begin{tabular}{ccccccc}
\hline Treatment & Plant Height & $\begin{array}{c}\text { No. Node on } \\
\text { main stem }\end{array}$ & $\begin{array}{c}\text { Internodal } \\
\text { length }\end{array}$ & $\begin{array}{c}\text { Number of } \\
\text { reproductive } \\
\text { branches }\end{array}$ & $\begin{array}{c}\text { Length of } 3^{\text {rd }} \\
\text { reproductive } \\
\text { Branch }\end{array}$ & Cotton yield \\
\hline $\begin{array}{c}\text { Nitrogen (Kg.h) } \\
0\end{array}$ & $72.93 \mathrm{~b}$ & $12.75 \mathrm{~b}$ & $5.71 \mathrm{~b}$ & $6.01 \mathrm{~b}$ & $18.68 \mathrm{~b}$ & $1469 \mathrm{~d}$ \\
75 & $73.47 \mathrm{~b}$ & $13.19 \mathrm{ab}$ & $5.85 \mathrm{~b}$ & $6.58 \mathrm{~b}$ & $21.27 \mathrm{~b}$ & $2532 \mathrm{~b}$ \\
150 & $75.71 \mathrm{~b}$ & $12.94 \mathrm{~b}$ & $5.89 \mathrm{~b}$ & $6.14 \mathrm{~b}$ & $18.54 \mathrm{~b}$ & $2825 \mathrm{a}$ \\
225 & $77.59 \mathrm{~b}$ & $14.44 \mathrm{a}$ & $5.95 \mathrm{~b}$ & $6.54 \mathrm{~b}$ & $18.11 \mathrm{~b}$ & $2829 \mathrm{a}$ \\
Pix (g.h) & & & & & & \\
0 & $90.94 \mathrm{a}$ & $13.86 \mathrm{a}$ & $6.57 \mathrm{a}$ & $7.2 \mathrm{a}$ & $22.54 \mathrm{a}$ & $2449 \mathrm{ab}$ \\
100 & $72.72 \mathrm{~b}$ & $13.22 \mathrm{ab}$ & $5.52 \mathrm{~b}$ & $6.05 \mathrm{~b}$ & $18.14 \mathrm{~b}$ & $2529 \mathrm{~b}$ \\
200 & $71.04 \mathrm{~b}$ & $12.52 \mathrm{bc}$ & $5.68 \mathrm{~b}$ & $6.02 \mathrm{~b}$ & $18.20 \mathrm{~b}$ & $2669 \mathrm{ab}$ \\
300 & $65 \mathrm{c}$ & $11.72 \mathrm{c}$ & $5.57 \mathrm{~b}$ & $6 \mathrm{~b}$ & $17.72 \mathrm{~b}$ & $2609 \mathrm{ab}$ \\
\hline
\end{tabular}

Numbers having common letters in each column are not significantly different at the probability level of 5 percent. 




Figure 1. Interaction effects of different levels of nitrogen and pix on plant height

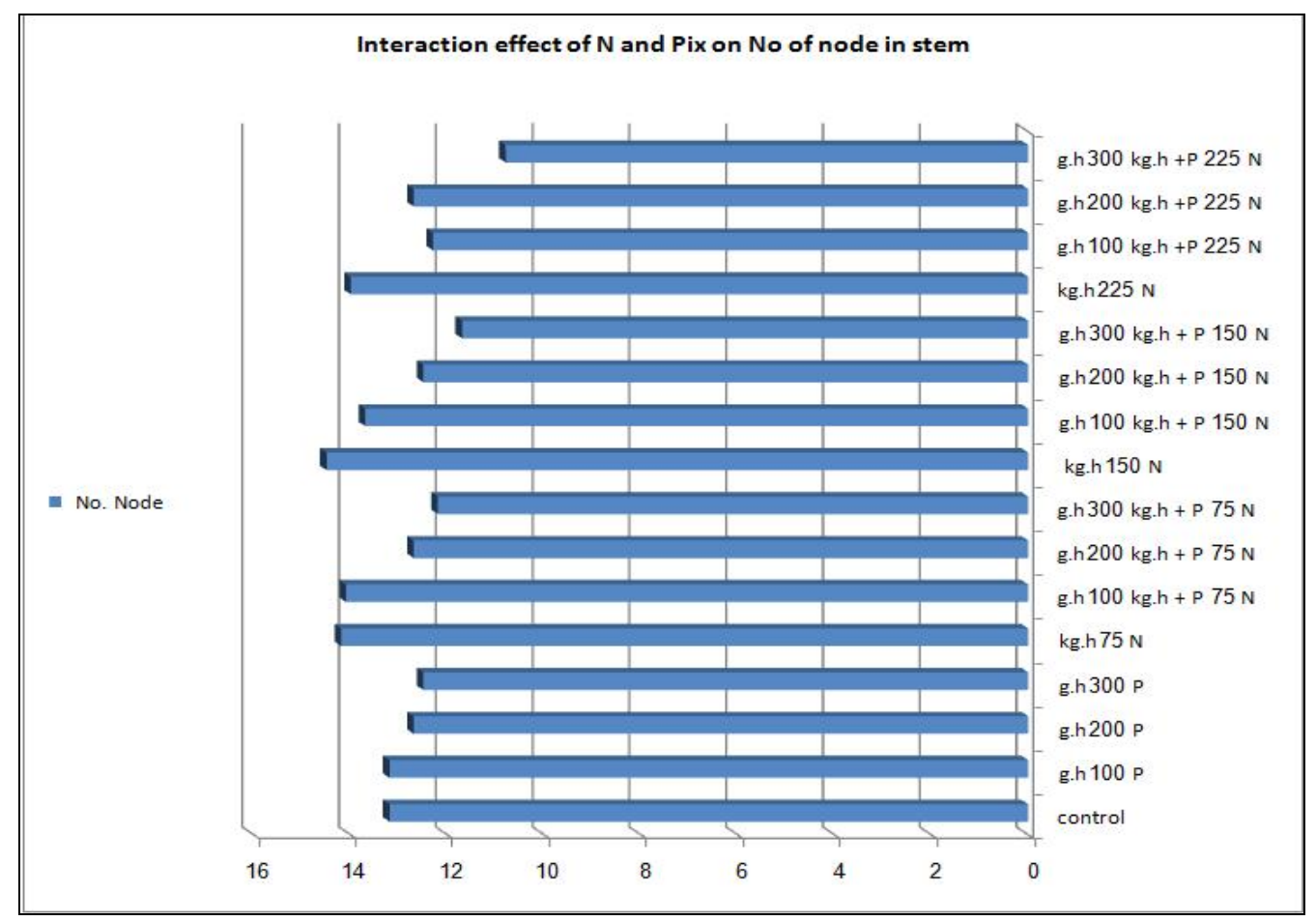

Figure 2. Interaction effects of different levels of nitrogen and pix on number of nod in stem

\subsection{Internodal Length on the Main Stem}

The length of the internodes on the main stem was also one of the features very significantly influenced by the 
application of Pix (Table 1). Comparison of the means indicated that use of Pix significantly decreased the length of the internodes, although changing the rate of applying Pix from 100 up to 300 g.h caused no significant change in the length of the internodes; however, the differences among the Pix control and the three levels of Pix application were very significant (Table 2). Therefore, another reason for the reduction in the height of the main stem, resulting from the application of Pix, is the reduction in the length of the internodes on the main stem. The effects of the various levels of using nitrogen were not significant regarding the length of the internodes on the main stem. The interaction effects of nitrogen plus Pix on the length of the internodes were not statistically significant either, but comparison of the means of the interaction effects indicated that there were significant differences between the interaction effects of these two factors. The two factors of nitrogen and Pix had various and different effects on the length of the internodes on the main stem: the longest internodes were seen in the treatment of urea control and Pix control, and the shortest $(4.9 \mathrm{~cm})$ in the treatment of urea control plus the application of 300 grams of Pix. In the treatment of applying 100 grams of Pix, there was not much difference in the length of the internodes when more urea was used. In the treatment of using $200 \mathrm{~g}$ of Pix, the length of the internodes increased when $150 \mathrm{Kg}$ of urea was applied; however, when urea was increased to $225 \mathrm{Kg}$, the length of the internodes decreased again. In the treatment of applying $300 \mathrm{~g}$ of Pix, the shortest internodes were observed at the level of urea control; and by increasing urea to $75 \mathrm{Kg}$ there was a rather big jump in the length of the internodes (but when urea was increased to $150 \mathrm{Kg}$, the length of the internodes declined again) (Figure $3)$.

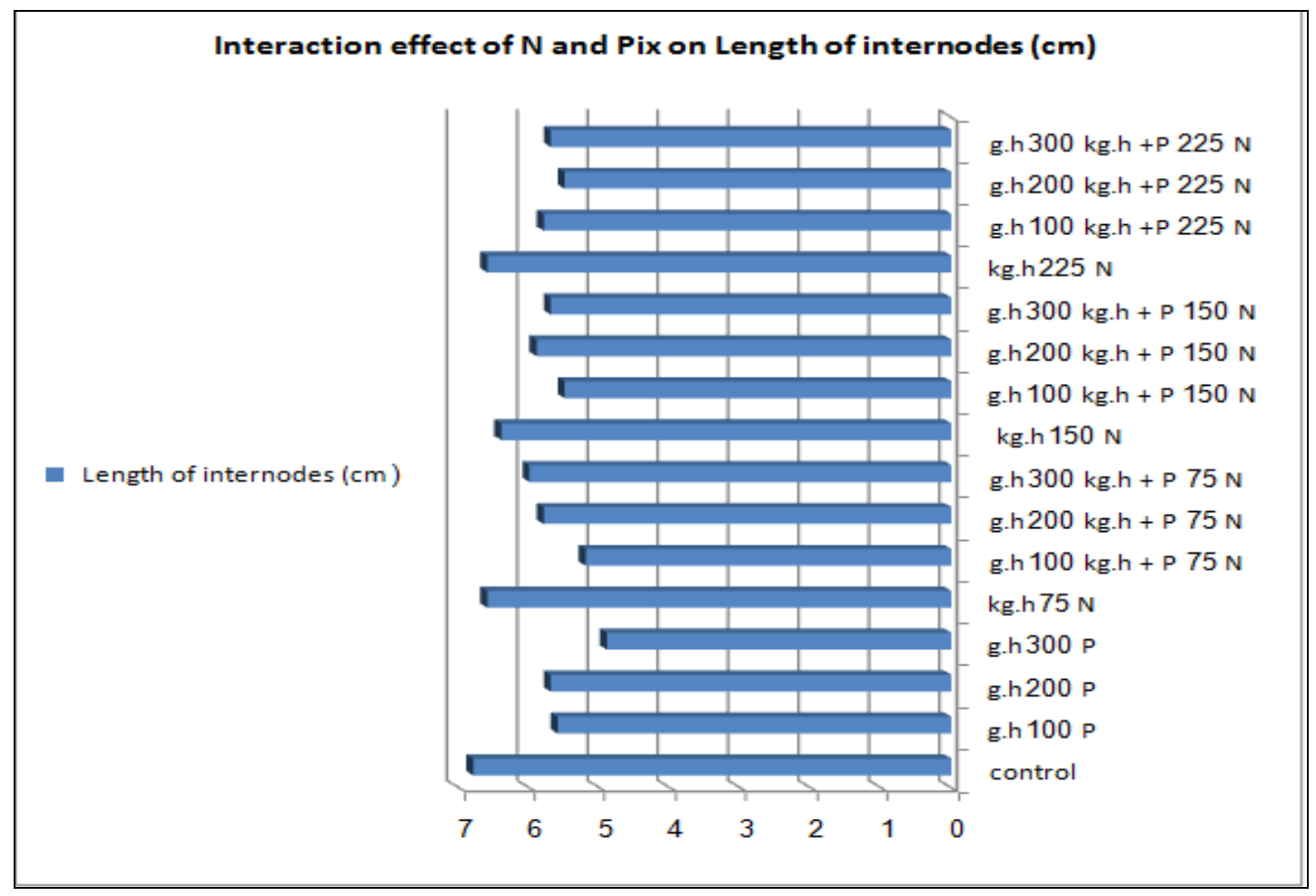

Figure 3. Interaction effects of different levels of nitrogen and pix on intermodal length

\subsection{Number of Reproductive Branches}

The differences among the various levels of nitrogen were not significant concerning the feature of the number of reproductive branches. However, the differences among the various levels of Pix, regarding the number of reproductive branches, were significant at the $5 \%$ probability level (Table 1). These results suggest that with an increase in the amount of Pix applied, the number of reproductive branches significantly declined; so that the greatest number of reproductive branches was achieved in the treatment of Pix control; and, with an increase in the amount of Pix, this number went down and reached the minimum of 6 branches per plant when $300 \mathrm{~g}$ of Pix was applied (Table 2). Comparison of the interaction effects of nitrogen and Pix showed that the maximum number of reproductive branches (7.5) was observed in the control, and the minimum number of nodes on the main stem (5.4) was obtained when $100 \mathrm{~g}$ of Pix was applied (Figure 4). 




Figure 4. Interaction effects of different levels of nitrogen and pix on reproductive stem

\subsection{The Length of the Third Reproductive Stem}

The differences among the various levels of nitrogen were not significant regarding the length of reproductive branches, but the differences among the various levels of Pix were very significant (Table 1). Comparison of the means indicated that when Pix was used, the length of the productive branches significantly decreased - i.e., in the Pix control the longest productive branches $(22.54 \mathrm{~cm})$ were achieved, while the treatment of applying $300 \mathrm{~g}$ of Pix had the shortest branches $(17.72 \mathrm{~cm}$ ) (Table 2). Comparison of the interaction effects of nitrogen and Pix showed that the maximum number of productive branches (7.5) belonged to the control, while the smallest number of nodes on the main stem (5.4) was observed in the treatment of using 100 grams of Pix (Figure 5).

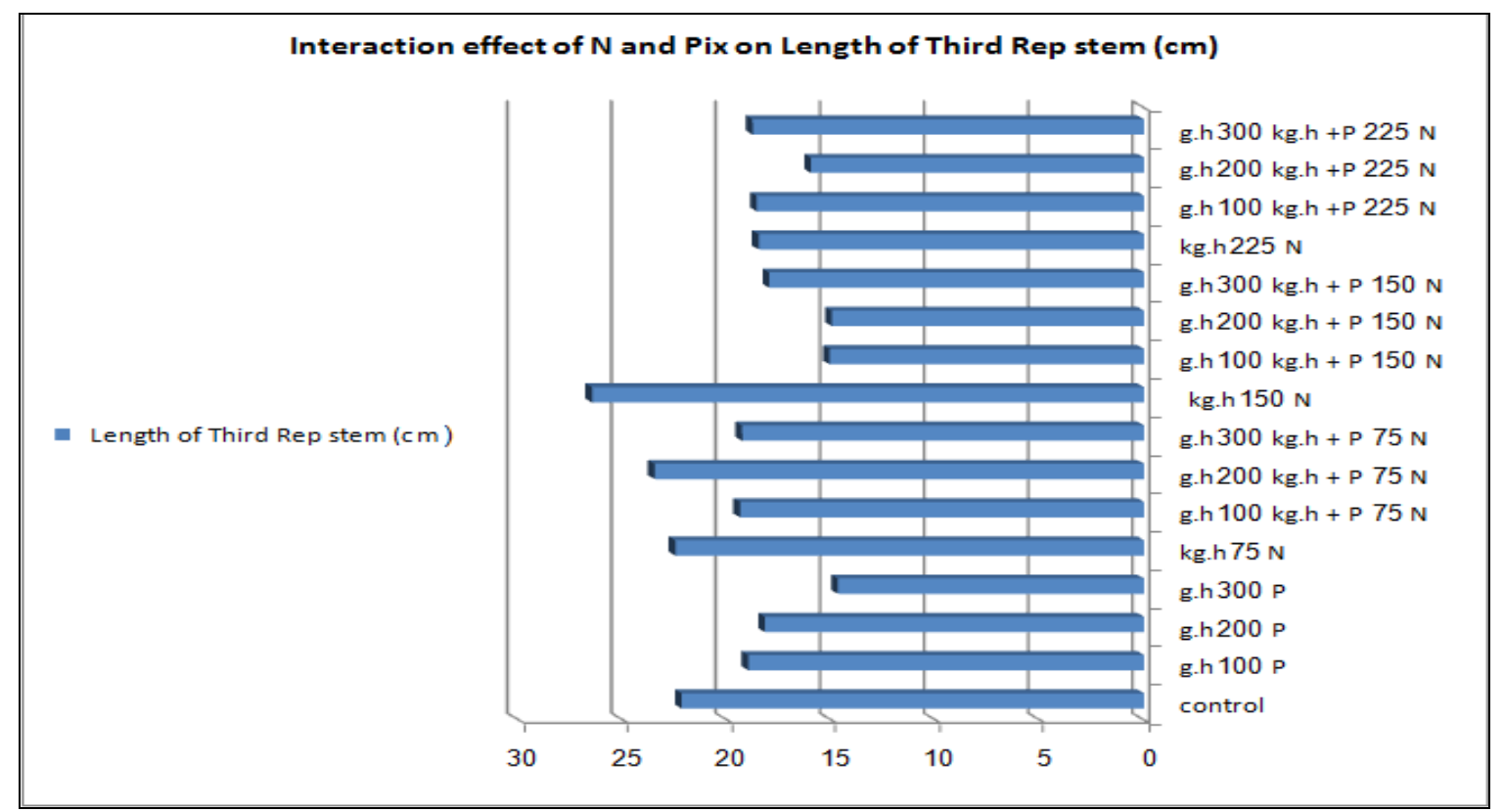

Figure 5. Interaction effects of different levels of nitrogen and pix on length of $3^{\text {rd }}$ reproductive branch 


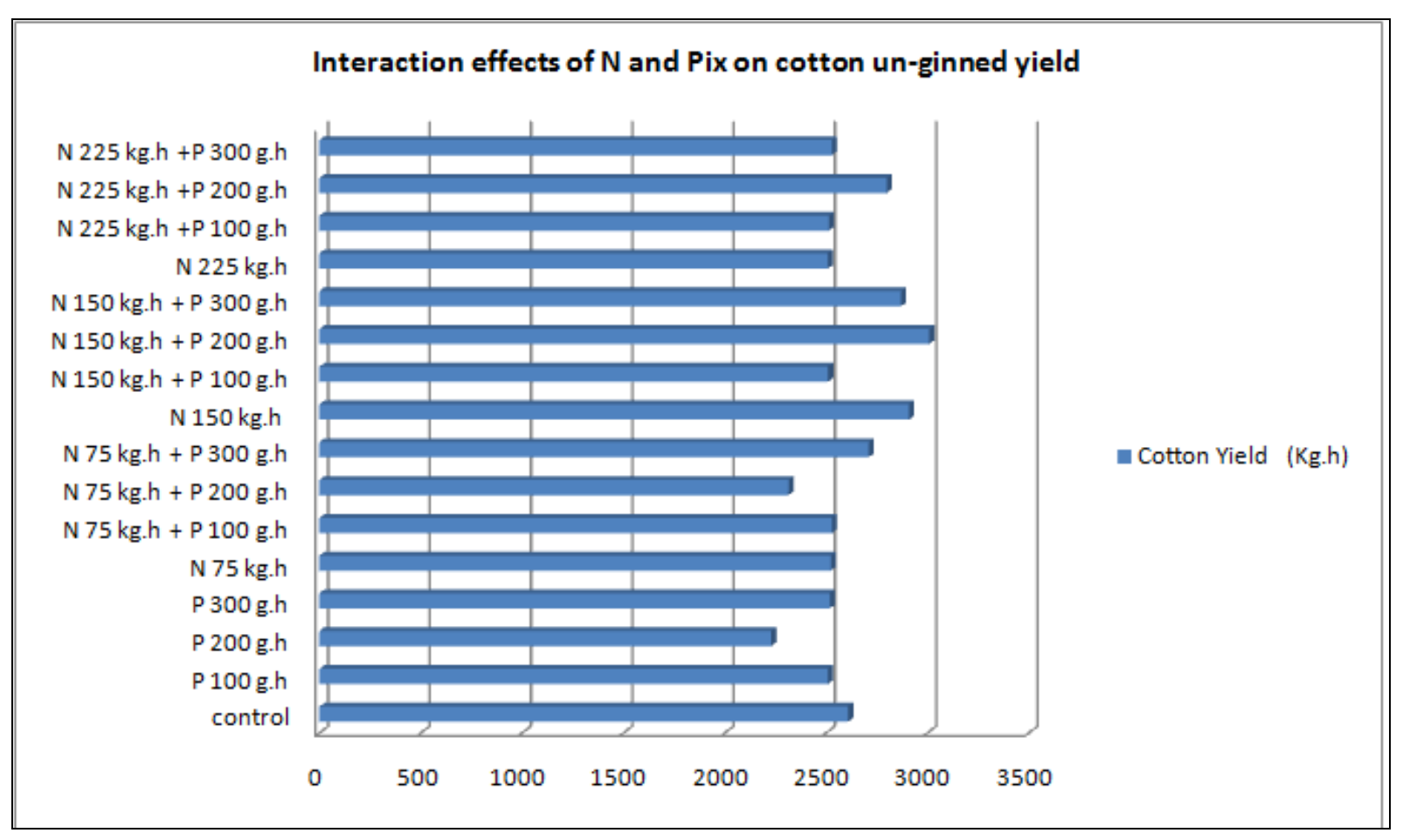

Figure 6. Interaction effects of different levels of nitrogen and pix on cotton un-ginned yield

\subsection{Unginned Cotton Yield}

Results of the analysis of the variance indicated that the effects of using different levels of nitrogen on the yield of unginned cotton were very significant (at the one percent probability level), but that the effects of various levels of using Pix and the interaction effects of nitrogen and Pix on unginned cotton yield were not significant (Table 1). Comparison of the means indicated that with an increase in nitrogen applied, the yield of unginned cotton very significantly went up; and this increase in the yield of unginned cotton continued up to the level of using $150 \mathrm{Kg} . \mathrm{h}$, after which (i.e., when $225 \mathrm{Kg}$ of nitrogen per hectare was used) the unginned cotton yield started to go down. In general, the minimum yield (1469 Kg of unginned cotton per hectare) was observed in the treatment of not applying nitrogen (the control), and the maximum (2825 Kg of unginned cotton per hectare) when $150 \mathrm{Kg}$ of nitrogen per hectare was used; that is, when $150 \mathrm{Kg} . \mathrm{h}$ of nitrogen was applied, the yield of unginned cotton went up by $14 \%$ (Table 2). These results are consistent with the findings of Abdolahi fard and Hemati (2003). Prokofev et al. (2007) reported that, in their research, with an increase in the levels of applied Pix, the yield of unginned cotton went up, while Armstrong et al. (2002) found that Pix reduced unginned cotton yield. In our study, Pix did not have much effect on increasing yield: the minimum unginned cotton yield (2529 Kg.h) was obtained in the treatment of using $100 \mathrm{~g}$ Pix per hectare, and the maximum ( $2669 \mathrm{Kg} . \mathrm{h})$ was achieved in the treatment of applying $200 \mathrm{~g}$ of Pix per hectare (Table 2). Comparison of the interaction effects of applying Pix and nitrogen indicated that the maximum unginned cotton yield among all the treatments $(3010 \mathrm{Kg} . \mathrm{h}) \mathrm{was}$ observed in the treatment of using $150 \mathrm{Kg}$ of nitrogen plus applying $200 \mathrm{~g}$ of Pix. These results also showed that the treatment of $150 \mathrm{Kg}$ of nitrogen, and that of $150 \mathrm{Kg}$ of nitrogen plus $300 \mathrm{~g}$ of Pix, also created the potential of producing high yields (close to 3 tons per hectare). The lowest yield (2230 Kg.h) was obtained in the treatment of $200 \mathrm{~g}$ of Pix (Figure 6).

\section{Conclusions}

It can be concluded from this research that with an increase in (the level of) nitrogen used, there was an increase in plant height, although this increase was not statistically significant. Furthermore, with an increase in the level of applied Pix, plant height very significantly decreased, the reason for which could be the inhibitory effect of Pix on the synthesis of gibberellic acid and on the elongation of the main stem. Increase in the level of applied Pix caused a reduction in the length of the internodes, and also a reduction in the number of nodes on the main stem. The reasons for the reduction in plant height resulting from the application of Pix could be attributed to the reduction in the length of the internodes and also to the reduction in the number of the nodes on the main stem. 
Pix reduced the number and the length of reproductive branches, so that these two features significantly decreased when Pix was applied.

\section{References}

Abdolahi Fard, K., \& Hadi, Hemati. (2003). Evaluation of effects of different levels of urea and nitrogen on cotton yield and quality. Final report. Cotton research center, p. 88.

Armstrong, J. F., Glat, D., Taylor, B. B., \& Buck Walte, H. (2002). Heat units as a method for timing Pix application. P. 570 in. J. M. Brown (ed). Proc Belt wide cotton prod. Res.conf. 3-7 Jan. Las vegas, Nv. Natl. cotton counc, AM. Memphis. T. N.

Carualho, L. H., Chlavegagto, E. J., \& Ecia, J. I., Kond, J. C., Sabino, A., Pettinelli Junior, N., \& Gallo, P. B. (2005). Plant growth regulator and pruning in the cotton crop. Field Crop Research, 72(10), 1033-1036.

Gerbin, P. M., Monteleone, \& Pardo, A. (1996). Effetcs of growth and regulator mepiquat chloride on shoot and root growth of irrigated cotton. Field Crop Research, 50(7), 680-684.

Kerby, T. A., \& Keeley, M. (1990). Genotypes and plant densities for narrow row cotton system, height nodes, $\begin{array}{llllll}\text { earliness and location } & \text { Crop }\end{array}$ http://dx.doi.org/10.2135/cropsci1990.0011183X003000030034x

Prokofev, A. A., Rasulow, S., \& Bokarev, K. S. (2007). Physiologically active substances as regulators of cotton growth and productivity. Plant Physiol, 54(4), 597-601.

Stuart, B. L., Isablee, V. R., Wendt, C. W., \& Abernathy, J. R. (2004). Modification of cotton water relations and growth with Mepiquate Chloride. Agronomy Journal, 96, 651-657. 